\title{
Freshwater mollusks from Neogene-Quaternary Dniester and Prut riverine deposits as indicator paleoenvironments: chemical composition of shells and its palaeoecological interpretation
}

\author{
AA Lyubas ${ }^{1}$, MB Kabakov ${ }^{1}$, VV Kriauciunas ${ }^{1}$, TF Obada $^{2}$, IN Nicoara ${ }^{3}$, AA Tomilova ${ }^{1}$ \\ 1 Laverov Federal Centre for Integrated Arctic Research, Russian Academy of Sciences (Arkhangelsk, Russian Federation) \\ 2 The Institute of Zoology, Academy of Sciences of the Republic of Moldova (Chișinău, Moldova) \\ 3 The Institute of Geology \& Seismology, Academy of Sciences of the Republic of Moldova (Chișinău, Moldova)
}

Corresponding author: Artem Lyubas (artem.lyubas@mail.ru)

Academic editor: Yuliya V. Bespalaya • Received 5 January 2019 • Accepted 21 February 2019 • Published 12 April 2019

Citation: Lyubas AA, Kabakov MB, Kriauciunas VV, Obada TF, Nicoara IN, Tomilova AA (2019) Freshwater mollusks from NeogeneQuaternary Dniester and Prut riverine deposits as indicator paleoenvironments: chemical composition of shells and its palaeoecological interpretation. Arctic Environmental Research 19(1): 35-42. https://doi.org/10.3897/issn2541-8416.2019.19.1.35

\begin{abstract}
The respective environments in two ancient rivers were studied using geochemical methods with paleogeographic reconstructions of fossil material represented by shells of freshwater bivalve mollusks. The studied outcrops are located in the basins of the Dniester and Prut rivers. Materials were collected from two Pliocene (Brînza, Giurgiulești) outcrops and the ages of the second group of localities (Sucleia, Slobozia Mare, Gura Bîcului) are from Middle to Late Pleistocene. The determination of the taxonomic position was carried out using standard malacological methods. Geochemical data were used for the environmental reconstruction and included stable isotope ratio and trace element compositions in subfossil freshwater bivalve shell (Bivalvia: Unionoida). Key indicators of paleoenvironments show changes in water temperature. Changes in the taxonomic composition of bivalve mollusk assemblages also occurred. In the present study, increasing the water temperature caused a change of stenobiont species of bivalve mollusks to eurybiont species. Eutrophication of watercourses, caused by anthropogenic pollution and climate change in the direction of warming, has led to the replacement of pearl mussels of the family Margaritiferidae by more eurybiont species of the family Unionidae in the benthic communities of European oligotrophic rivers. These processes are similar to those deduced for the Neogene-Quaternary watercourses of the Prut and Dniester basins, but they proceed at a much faster pace. They are processes of eutrophication of watercourses - the main factor leading to the catastrophically rapid modern reduction of the ranges of pearl mussel.
\end{abstract}

Copyright Lyubas AA et al. This is an open access article distributed under the terms of the Creative Commons Attribution License (CC-BY 4.0), which permits unrestricted use, distribution, and reproduction in any medium, provided the original author and source are credited. 


\section{Keywords}

freshwater bivalve mollusks, elemental composition, stable isotope ratio, paleoclimate, Neogene-Quaternary

riverine deposits

\section{Introduction}

The Neogene-Quaternary riverine deposits of the Russian Plain are the focus of attention for geologists, geographers, and paleontologists. In the literature (e.g., Matoshko et al. 2004), it is noted that they have a role as natural archives which make it possible to reconstruct the environment of the past. Further, the application of the methods of modern paleogeography to various fossil materials is currently particularly relevant. For example, mollusks, as filtering organisms, are a source of information about the environment in ancient rivers. Fossil shells of mollusks are widely used in paleogeographic studies (Yan et al. 2014) and hydroclimatic reconstructions (Geist et al. 2005, Schöne et al. 2007). Various methods have been developed to obtain information on environmental conditions in the historical and geological past. Among them, geochemical methods are quite effective and represent the analysis of ratios of stable oxygen isotopes (Goodwin et al. 2003) and carbon isotopes (Fritz and Poplawski 1974, Latal et al. 2004), and an analysis of the content of trace elements in the carbonate of shells (Bolotov et al. 2015). Techniques such as laser ablation, for example, allow the detection of changes in hydroclimatic conditions in a waterbody during the life of a mollusk, based on an analysis of the layers in the shell cut (Schöne et al. 2010). Lower resolution methods are used to reconstruct paleoecological conditions of the geological past. There are numerous examples of such usage of geochemical data (Jass et al. 2002, Kieniewicz and Smith 2007, Wang et al. 2016). Based on this, an application of geochemical methods to fossil shells of freshwater bivalve mollusks from Neogene-Quaternary localities in the south of the Russian Plain was undertaken in this research. The main goal of this work was the reconstruction of some parameters of the aquatic environment in the Pliocene and Pleistocene biotopes in the Prut and Dniester river basins.

\section{Materials and methods}

The studied outcrops are located in the basins of the Dniester and Prut rivers (Fig. 1). Their descriptions are presented in Table 1. The names of the localities are given with respect to nearby settlements. A detailed description of the studied localities, outcrops and their geological ages are developed in Vangengeym et al. (2005), Yanshin (1989), Adamenko (1986), Titov (2008), and Tesakov (2004). In those studies, materials were collected from two Pliocene (Brînza, Giurgiuleşti) outcrops and the ages of the second group of localities (Sucleia, Slobozia Mare, Gura Bîcului) are from Middle to Late Pleistocene.

The materials for the study were subfossil shells of freshwater bivalve mollusks, belonging to the genera Margaritifera and Unio (Fig. 2).

The collecting of mollusk shells during the fieldwork consisted of clearing of an outcrop in the locality, and layer-by-layer descriptions of the sediments of the entire section. Before collecting any fossil materials, their respective positions in the sediments and relation to each other along the strike (by area), and along the outcrop, were recorded (Lavrov and Kupman 1989). The collecting of subfossil materials was carried out from 1 to 20 May 2013.

The determination of the taxonomic position was carried out in accordand with the methods described in Chepalyga (1967) and Araujo et al. (2009). For chemical analyses, the shell fragments from the umbo area were pre-ground in an agate mortar.

Concentrations of $\mathrm{Mg}, \mathrm{Ca}, \mathrm{Fe}$ in the carbonate of subfossil mollusk shells were determined using atomic emission spectrometry (AES) with inductively coupled plasma (ICP, iCAP-6500, Thermo Scientific, USA). Concentrations of $\mathrm{Mn}, \mathrm{Sr}, \mathrm{Ba}$ in the shell material were determined using inductively coupled plasma mass spectrometry (ICP-MS, X-7, 


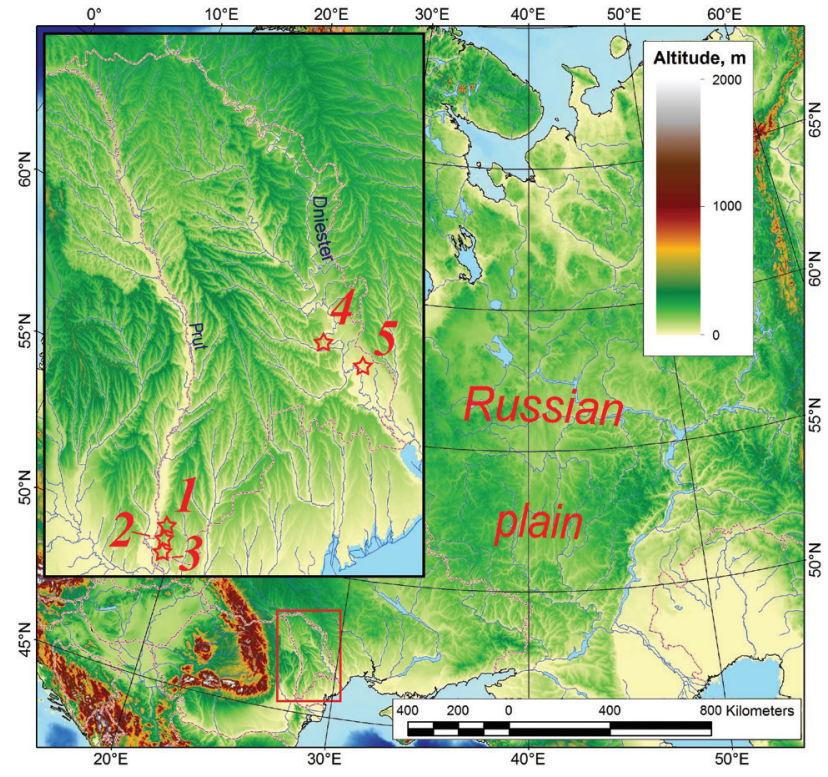

Fig. 1. Location map of the field study areas. 1 - Brînza, 2 Slobozia Mare, 3 - Giurgiuleşti, 4 - Gura Bîcului, 5 - Sucleia

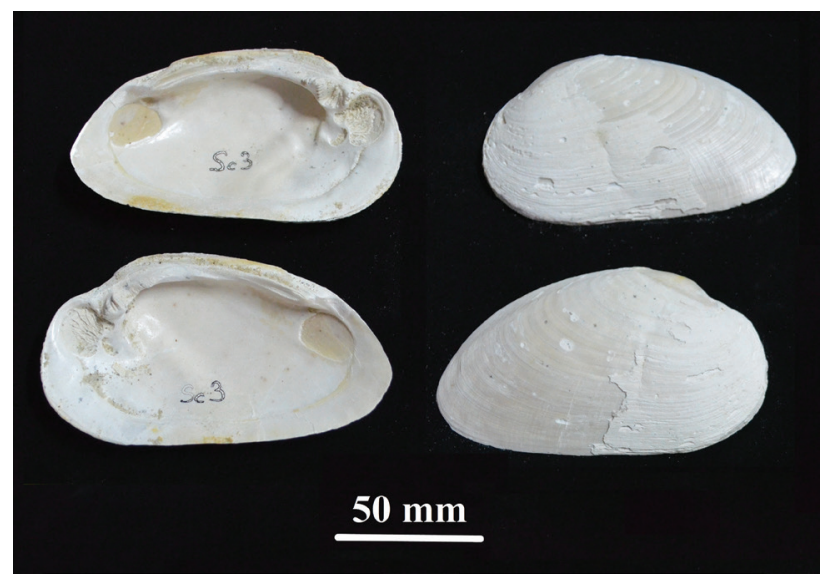

Fig. 2. Subfossil shell of freshwater bivalve mollusk Margaritifera (Pseudunio) spp.
Thermo Elemental, USA) (Karandashev et al. 2016, Shevchenko et al. 2017).

The isotope composition of carbon and oxygen in the shell material was determined at the Geological Institute of the Siberian Branch of the Russian Academy of Sciences (Ulan-Ude, The Republic of Buryatia, Russia) using the Finningan MAT253 mass spectrometer (Thermoscientific). The measurements were carried out in the form of $\mathrm{CO}_{2}$ in the mode of a continuous flow of helium using the GasBench mass spectrometer configuration. International standards NBS-18 and NBS-19 were used to calculate $\delta^{13} \mathrm{C}$ and $\delta^{18} \mathrm{O}$. The accuracy of the obtained values was monitored by taking regular measurements of the Russian standards MSA7, MSA-8 (Far East Geological Institute at the Far Eastern Branch of the Russian Academy of Sciences, FEGI FEB RAS). The repeatability of the obtained values was $\pm 0.2 \%$.

The Kruskal-Wallis $\mathrm{H}$ test was used for the measurement of the differences between the content of chemical elements in fossil mollusk shells, and these data were ranked. Ranking consisted of the transition from the quantitative values of the concentrations of chemical elements to the ranks, which were subsequently compared with each other. To identify statistically significant differences in the content of chemical elements between two sample groups of different ages, the nonparametric Mann-Whitney $\mathrm{U}$ test was used. Cluster analysis of geochemical data was carried out to classify the localities in accordance with redox conditions in ancient biotopes. Statistical data processing was performed using StatSoft, Inc. (2011), STATISTICA (data analysis software system), version 10 .

Table 1. List of studied localities

\begin{tabular}{|c|c|c|c|c|c|}
\hline № & Locality & District, country & Coordinates & River basin & Hosting deposits \\
\hline 1 & Brînza & Cahul District, Moldova & $45^{\circ} 39^{\prime} 26^{\prime \prime} \mathrm{N} 28^{\circ} 10^{\prime} 24^{\prime \prime} \mathrm{E}$ & Prut & $\begin{array}{l}\text { Yellowish-orange ferruginized sand and subjacent } \\
\text { layer braun pebble }\end{array}$ \\
\hline 2 & Slobozia Mare & Cahul District, Moldova & $45^{\circ} 36^{\prime} 24^{\prime \prime} \mathrm{N} 28^{\circ} 9^{\prime} 56^{\prime \prime} \mathrm{E}$ & Prut & Braun pebble with ferruginized sand \\
\hline 3 & Giurgiuleşti & Cahul District, Moldova & $45^{\circ} 29^{\prime} 3^{\prime \prime} \mathrm{N} 28^{\circ} 11^{\prime} 0^{\prime \prime} \mathrm{E}$ & Prut & $\begin{array}{l}\text { Yellowish friable sand with clay's lens and inclusions } \\
\text { small pebble }\end{array}$ \\
\hline 4 & Gura Bîcului & Anenii Noi District, Moldova & $46^{\circ} 57^{\prime} 4^{\prime \prime} \mathrm{N} 29^{\circ} 27^{\prime} 13^{\prime \prime} \mathrm{E}$ & Dniester & Coarse pebble with sand's interbeds \\
\hline 5 & Sucleia & $\begin{array}{l}\text { Slobozia District of } \\
\text { Transnistria, Moldova }\end{array}$ & $46^{\circ} 49^{\prime} 59^{\prime \prime}$ N 29² $42^{\prime} 6^{\prime \prime} \mathrm{E}$ & Dniester & $\begin{array}{l}\text { Smalls light brown pebble with gray sand and } \\
\text { underlying coarse pebbles' layer }\end{array}$ \\
\hline
\end{tabular}




\section{Results}

The chemical characteristics of the carbonate of the studied shells are presented in Supplementary material 1, 2 (Tables S1, S2). High concentrations of Fe, Mn, $\mathrm{Sr}$ were measured. The mean concentrations of $\mathrm{Mn}$ in the materials of the shells are from $214.9 \pm 42.3 \mathrm{mg} /$ $\mathrm{kg}$ to $434.7 \pm 71.5 \mathrm{mg} / \mathrm{kg}$, the average amounts of $\mathrm{Fe}$ and $\mathrm{Sr}$ are from $60.5 \pm 19.8 \mathrm{mg} / \mathrm{kg}$ to $868.5 \pm 233.4 \mathrm{mg} /$ $\mathrm{kg}$ and from $537 \pm 47.8 \mathrm{mg} / \mathrm{kg}$ to $2001.5 \pm 172.2 \mathrm{mg} /$ $\mathrm{kg}$, respectively. These are typical indicators for the elemental composition of freshwater riverine bivalve mollusk shells. The measured $\delta^{13} \mathrm{C}$ and $\delta^{18} \mathrm{O}$ values are in the ranges from $-12.1 \%$ to $-10.35 \%$ for stable isotope of carbon-13 and from $20.44 \%$ to $22.41 \%$ for stable isotope of oxygen-18. Such values of these indicators are not abnormal for such material.

\section{Discussion}

For reconstruction of the redox conditions in ancient river biotopes, changes in the $\mathrm{Mn} / \mathrm{Fe}$ ratios in fossil shells from the studied sites were analyzed (Fig. 3). This geochemical indicator shows that the highest concentrations of oxygen in water are found in paleobiotopes, which have been reconstructed based on data obtained from the Sucleia and Gura Bîcului outcrops. Coarse deposits, represented by pebbles and gravel, interbedded with coarse sand were investigated. The lowest values of $\mathrm{Mn} / \mathrm{Fe}$ are characteristic of the location of Giurgiuleşti and Brînza. Here, a layer of a pebble, bordering on ferruginized sand, has less thickness, than in the outcrops of Sucleia and Gura Bîcului.

Based on the results obtained by comparing individual locations using the Kruskal-Wallis $\mathrm{H}$ test

Table S1. Elemental composition of the subfossil bivalve shells from studied outcrops.

\begin{tabular}{ccccccccc}
\hline Locality & Mollusks taxa & $\begin{array}{c}\text { Number of } \\
\text { samples }\end{array}$ & Mn, ppm & Fe, ppm & Ba, ppm & Sr, ppm & Mg, ppm & Ca, ppm \\
\hline Brînza & Margaritifera & 5 & $282.9 \pm 25.2$ & $868.5 \pm 233.4$ & $65.2 \pm 7.5$ & $537.0 \pm 47.8$ & $44.5 \pm 3.9$ \\
Slobozia Mare & Unio & 5 & $231.9 \pm 51.8$ & $258.5 \pm 86.6$ & $54.1 \pm 4.9$ & $687.0 \pm 33.1$ & $71.6 \pm 16.9$ & $3878555.0 \pm 4696.0$ \\
Giurgiuleşti & Margaritifera & 5 & $369.2 \pm 108.2$ & $681.7 \pm 396.8$ & $51.6 \pm 7.7$ & $654.1 \pm 108.1$ & $140.9 \pm 88.1$ & $396040.8 \pm 3750.2$ \\
Gura Bîcului & Unio & 5 & $434.7 \pm 71.5$ & $127.5 \pm 72.8$ & $43.6 \pm 7.0$ & $1220.9 \pm 70.6$ & $16.9 \pm 4.9$ & $389267.9 \pm 4960.2$ \\
Sucleia & Margaritifera & 5 & $214.9 \pm 42.3$ & $60.5 \pm 19.8$ & $176.9 \pm 49.3$ & $2001.5 \pm 172.2$ & $38.3 \pm 2.3$ & $401224.8 \pm 2871.1$ \\
\hline
\end{tabular}

Table S2. Stable isotope ratio $\delta 13 \mathrm{C}$ and $\delta 18 \mathrm{O}$ in the subfossil bivalve shells from studied outcrops.

\begin{tabular}{|c|c|c|c|c|}
\hline Locality & Mollusk's taxa & Number of samples & 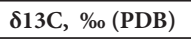 & $\delta 180, \%$ (VSMOW) \\
\hline Brînza & Margaritifera & 5 & $-12.1 \pm 0.38$ & $22.41 \pm 0.11$ \\
\hline Slobozia Mare & Unio & 5 & $-11.54 \pm 0.37$ & $21.84 \pm 0.04$ \\
\hline Giurgiulești & Margaritifera & 5 & $-12.16 \pm 0.36$ & $21.97 \pm 0.18$ \\
\hline Gura Bîcului & Unio & 5 & $-10.35 \pm 0.48$ & $20.44 \pm 0.02$ \\
\hline Sucleia & Margaritifera & 5 & $-10.42 \pm 0.47$ & $21.39 \pm 0.11$ \\
\hline
\end{tabular}

$(\mathrm{p}=0.022)$, groups of Pliocene and Pleistocene sections were compared using the Mann-Whitney $\mathrm{U}$ test. Statistically significant differences in the $\mathrm{Mn} /$ $\mathrm{Fe}$ ratios were found $(\mathrm{p}=0.024)$. The average rank is higher in the Pleistocene outcrops.

The geochemical indicator $\mathrm{CaO} / \mathrm{MgO}$ is directly related to temperature (Lukashev 1972). Its use, in being applied to the fossil shells under consideration, allowed us to compare the temperature conditions in which the malacocenoses developed. To contrast the indicator values in subfossil shells from five different localities, we used the Kruskal-Wallis $\mathrm{H}$ test, which allowed us to reveal statistically significant differences between them $(p=0.009)$. The warmest conditions were reconstructed for the Gura Bîcului locality, and there we found mollusk taphocenoses with the largest number of species, including those belonging to the genus Unio. The lowest values of the $\mathrm{CaO} / \mathrm{MgO}$ ratio were obtained for outcrops located in the Prut river basin. There were no statistically significant differences in the values of this indicator between the Pleistocene and Pliocene localities $(\mathrm{p}=0.079)$.

The $\mathrm{Ba} / \mathrm{Sr}$ indicator has an inverse correlation with water temperature. According to this indicator, its 


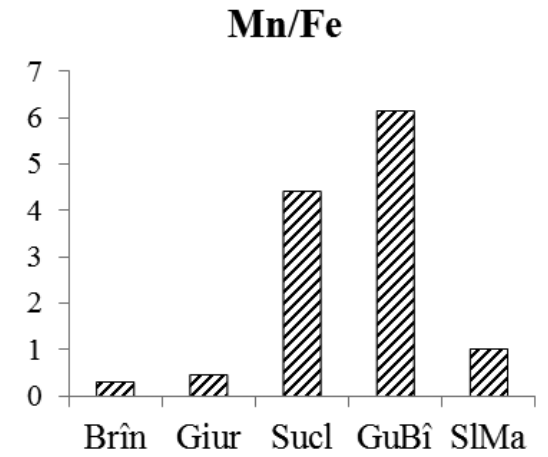

$\mathrm{Sr} / \mathrm{Ca}$

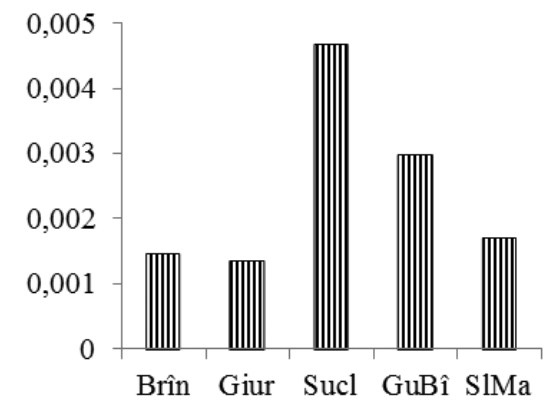

$\mathrm{CaO} / \mathrm{MgO}$

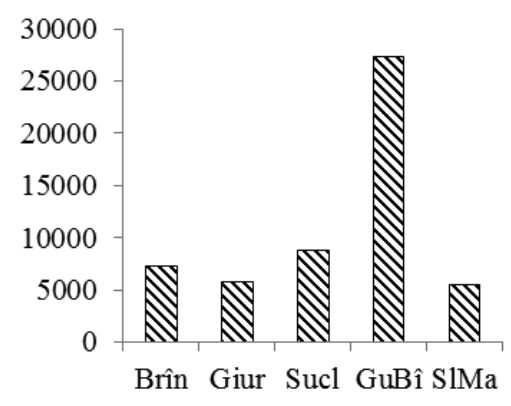

$\mathrm{Ba} / \mathrm{Sr}$

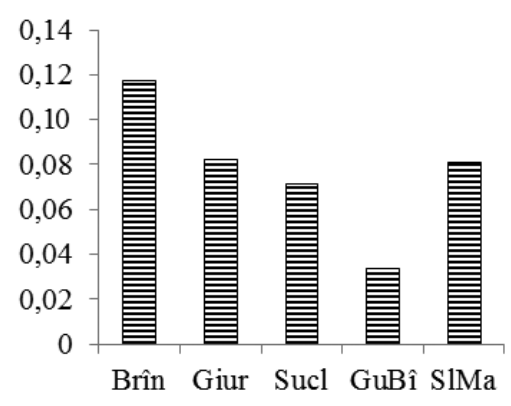

Fig. 3. Change of median values of the studied geochemical indicators in the period from Pliocene to Late Pleistocene in subfossil shells of freshwater mollusks (Bivalvia: Unionoida): Brîn - Brînza, Giur - Giurgiuleşti, Sucl - Sucleia, GuBî - Gura Bîcului, SlMa - Slobozia Mare

highest values are measured for shells from the Brînza outcrop. The warmest conditions of sedimentation existed in paleobiotopes reconstructed from materials from the Gura Bîcului outcrops. It is noteworthy that they are of a young age. Using the Kruskal-Wallis $\mathrm{H}$ test, the difference in $\mathrm{Ba} / \mathrm{Sr}$ index values was proved between samples from certain localities $(p=0.003)$ and using Mann-Whitney $U$ criteria, the difference in $\mathrm{Ba} / \mathrm{Sr}$ index values was proved between Pliocene and Pleistocene biotopes ( $\mathrm{p}=0.006$ ). Warmer hydroclimatic conditions existed in the Pleistocene ecosystems.

Data on the depth of the rivers in paleobiotopes were obtained on the basis of the Sr/Ca ratio. According to our data, the Dniester River sections reconstructed along the Sucleia and Gura Bîcului outcrops had the greatest depth; the shallowest depth was observed in the locations of Brînza and Giurgiuleşti, respectively (Kruskal-Wallis $\mathrm{H}$ test, $\mathrm{p}=0.001$ ). Using the Mann-Whitney $U$ test allowed us to conclude that there are statistically significant differences between the samples of Pliocene and Pleistocene shells $(p=0.002)$. The greatest depths of the considered sections of the rivers were in the Pleistocene.

The $\delta^{13} \mathrm{C}$ variations are significantly different in the shells from the five outcrops $(\mathrm{p}=0.021)$ under study. The highest values of this indicator are peculiar to Pleistocene localities, and in Pliocene shells the values are lower $(p=0.003)$. The variation in $\delta^{13} \mathrm{C}$ values over time indicates a change in the trophic status of river ecosystems.

The $\delta^{18} \mathrm{O}$ values, measured in the material of mollusk shells, are inversely correlated with the water temperature in which the mollusk lived, and based on this indicator, it is possible to obtain some idea about the change of hydroclimate in ancient rivers (Kelemen et al. 2017). In our case, statistically significant differences exist both between samples from certain outcrops $(\mathrm{p}=0.0005)$ and between groups of different ages $(p=0.0005)$. Warmer environments were specified for the Pleistocene paleobiotopes that were reconstructed from data from the Gura Bîcului and Sucleia sites. 


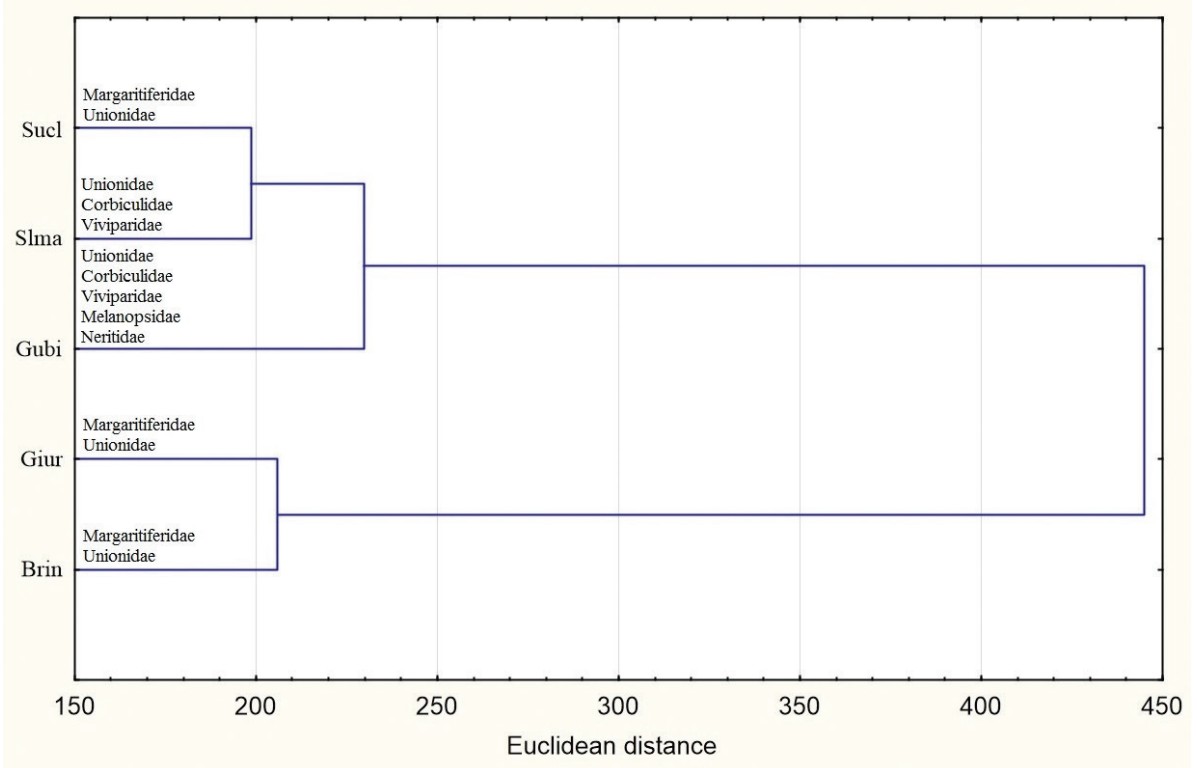

Fig. 4. Cluster analysis diagram based on the data on Fe, Mn concentrations and isotopic ratios $\delta^{13} \mathrm{C}$ and $\delta^{18} \mathrm{O}$ in the carbonate of shells from localities of different age with information about the taxonomic composition of subfossil mollusk taphocenoses: Brîn - Brînza, Giur - Giurgiuleşti, Sucl - Sucleia, Gubî - Gura Bîcului, Slma - Slobozia Mare

Figure 4 shows the change in the taxonomic composition of the fossil mollusk taphocenoses in Pliocene and Pleistocene sediments of the Dniester and Prut rivers that were dependent on the paleoenvironments in ancient biotopes. To assess the hydroclimatic situation, data on variations of $\delta^{13} \mathrm{C}$ and $\delta^{18} \mathrm{O}$ and concentrations of $\mathrm{Mn}$ and $\mathrm{Fe}$ in fossil shells were used here.

Two reconstructed Pliocene biotopes in localities in the Prut river basin (Giurgiulesti, Brynza) were distinguished by a relatively low content of organic matter, as well as a low water temperature during the period of sedimentation. Using the $\mathrm{Fe} / \mathrm{Mn}$ ratio, the biotope in which the mollusks lived can be characterized as a shallow section of a river with a sandy bottom. The result of the combination of these factors was the development of Margaritiferid assemblages in particular populations in which the species of pearl mussels Margaritifera flabellatiformis dominated.

The Pleistocene sites of Sucleia and Gura Bîcului have a layer of coarse-grained sediments with numerous mollusk shells in the outcrop. High values of the $\mathrm{Mn} / \mathrm{Fe}$ ratio indicate high oxygen-enriched waters during sedimentation, which led to the development of the Gastropoda and Bivalvia assemblages that were found here. Using the materials obtained from Slobozia-Mare, we reconstructed the meso-eutrophic environment of the watercourse and compared it with the low $\mathrm{Mn} / \mathrm{Fe}$ ratio of Sucleia, which indicates low oxygen concentrations in the waters of the ancient river, and this explains the of freshwater pearl mussels in taphocenoses and their depleted species composition.

The elemental composition changes of the studied mollusk shells are consistent with the granulometric composition of the sediments, characteristic of certain paleoecological conditions. On the basis of geochemical indicators, such as the ratio $\mathrm{Ba} / \mathrm{Sr}$ and $\delta^{18} \mathrm{O}$, we note that there was an increase in water temperature during the development of the river ecosystem. It is likely that this led to the complete displacement of freshwater pearl mussels, living in waters with low organic content, to bivalve mollusks from family Unionidae, which can successfully live in eutrophic water.

Summarizing the data obtained on the studied indicators of palaeoecological conditions, we conclude that in benthic assemblages of oligotrophic rivers in the Neogene-Quaternary river basins of Prut and Dniester rivers, stenobiont species of pearl mussels from family Margaritiferidae were the domi- 
nant freshwater mussel group up to the Middle Pleistocene. Pearl mussel shells are massively represented in the Pliocene and Middle Pleistocene alluvial sediments that were studied. However, with climate change and the eutrophication of watercourses, the role of pearl mussels in these communities declined, and the pearl mussels were replaced by more eurybiontic mollusks species from family Unionidae which are, currently, the only large bivalve mollusks in the Dniester and Prut river basins.

Modern global eutrophication of watercourses, caused by anthropogenic pollution and climate change in the direction of warming (Fritts et al. 2017, Lundquist et al. 2019), leads to the replacement of pearl mussels of the family Margaritiferidae by more eurybiont species of the family Unionidae in the benthic communities of European oligotrophic rivers. These processes are similar to those deduced for the Neogene-Quaternary watercourses of the Prut and Dniester basins, but proceed at a much faster pace. The processes of eutrophication of watercourses are the main factor leading to the catastrophically rapid modern reduction of the ranges of pearl mussel. The data obtained in this study indicate the need to develop pan-European programs on the problem of eutrophication of oligotrophic rivers, otherwise, there is a risk of extinction of the remaining populations of pearl mussels in Europe (Bolotov et al. 2018).

\section{References}

- Adamenko OM (1986) Anthropogen and Paleolithic Moldavian Transnistria. Excursion guide $6^{\text {th }}$ All-Union meeting on the study of the Quaternary period. Chisinau, Stiinta, $155 \mathrm{pp}$.

- Araujo R, Reis J, Machordom A, Toledo C, Madeira MJ, Gomez I, Velasco JC, Morales J, Barea JM, Ondina P, Ayala I (2009) Las náyades de la península Ibérica. Iberus 27(2): 7-72. http://hdl.handle.net/10261/45260

- Bolotov IN, Pokrovsky OS, Auda Y, Bespalaya JV, Vikhrev IV, Gofarov MY, Lyubas AA, Viers J, Zouiten C (2015) Trace element composition of freshwater pearl mussels Margaritifera spp. across Eurasia: Testing the effect of species and geographic location. Chemical Geology 402: 125-139. https://doi. org/10.1016/j.chemgeo.2015.03.006

\section{Conclusion}

Based on geochemical indicators of environments, it was revealed by the results of the present study that an increase in water temperature in the studied ancient biotopes was accompanied by eutrophication of watercourses. At the same time, there was a change in the taxonomic composition of the bivalve mollusk assemblages in ancient rivers. The status of the primary oligotrophic rivers Dniester and Prut over long-term periods (several million years) changed significantly up to them being organic-enriched eutrophic watercourses. Further studies of fluvial 'archives', paleoecology of freshwater mussels, and Neogene-Quarternary paleogeography of the southwestern part of the Russian Plain should be focused on while using new methods of dating and environmental reconstruction of Pliocene and Pleistocene fossils and deposits.

\section{Acknowledgements}

The study was carried out by a grant from the Russian Science Foundation (project № 18-77-00058).

Bolotov IN, Makhrov AA, Gofarov MYu, Aksenova OV, Aspholm PE, Bespalaya YuV, Kabakov MB, Kolosova YuS, Kondakov AV, Ofenböck T, Ostrovsky AN, Popov IYu., von Proschwitz T, Rudzīte M, Rudzītis M, Sokolova SE, Valovirta I, Vikhrev IV, Vinarski MV, Zotin AA (2018) Climate Warming as a Possible Trigger of Keystone Mussel Population Decline in Oligotrophic Rivers at the Continental Scale. Scientific Reports 8(35): 1-10. https://doi.org/10.1038/s41598-017-18873-y

- Chepalyga AL (1967) Antropogenovye presnovodnye mollyuski yuga Russkoj ravniny i ih stratigraficheskoe znachenie. Moscow, Nauka, 222 pp. http://www.ginras.ru/library/ pdf/166_1967_chepalyga_antropog_molluscs.pdf

- Fritts AK, Fritts MW, Haag WR, DeBoer JA, Casper AF (2017) Freshwater mussel shells (Unionidae) chronicle changes in a 
North American river over the past 1000 years. Science of The Total Environment 575: 199-206. https://doi.org/10.1016/j. scitotenv.2016.09.225

- Fritz P, Poplawski S (1974) ${ }^{18} \mathrm{O}$ and ${ }^{13} \mathrm{C}$ in the shells of freshwater mollusks and their environment. Earth and Planetary Science Letters 24: 91-98.https://doi.org/10.1016/0012-821X(74)90012-0

- Geist J, Auerswald K, Boom A (2005) Stable carbon isotopes in freshwater mussel shells: environmental record or marker for metabolic activity? Geochim. Cosmochim. Acta 69: 35453554. https://doi.org/10.1016/j.gca.2005.03.010

- Goodwin DH, Schöne BR, Dettman DL (2003) Resolution and fidelity of oxygen isotopes as paleotemperature proxies in bivalve mollusk shells: Models and observations. Palaios 18: 110-125. https://doi.org/10.1669/0883-1351(2003)18<11 $0:$ RAFOOI $>2.0 . \mathrm{CO} ; 2$

- Jass CN, Mead JI, Morrison AD, Agenbroad LD (2002) Late Pleistocene mollusks from the southern Black Hills, South Dakota. Western North American Naturalist 62(2): 129-140. https://scholarsarchive.byu.edu/wnan/vol62/iss2/1

- Karandashev VK, Hvostikov VA, Nosenko SV, Burmij ZhP (2016) Highly Enriched Stable Isotopes in Large Scale Analysis of Rocks, Soils, Subsoils and Bottom Sediments Using Inductively Coupled Plasma Mass Spectrometry (ICP-MS). Zavodskaya laboratoriya. Diagnostika materialov 82(7): 6-15. https://elibrary.ru/item.asp?id=26681852

- Kelemen Z, Gillikin DP, Graniero LE, Havel H, Darchambeau F, Borges AV, Yambélé A, Bassirou A, Bouillon S (2017) Calibration of hydroclimate proxies in freshwater bivalve shells from Central and West Africa. Geochimica et Cosmochimica Acta 208: 41-62. https://doi.org/10.1016/j.gca.2017.03.025

- Kieniewicz J, Smith J (2007) Hydrologic and climatic implications of stable isotope and minor element analyses of authigenic calcite silts and gastropod shells from a mid-Pleistocene pluvial lake, Western Desert, Egypt. Quaternary Research 68(3): 431-444. https://doi.org/10.1016/j.yqres.2007.07.010

- Lavrov VV, Kupman AS (1989) Field Geology - Reference Guide. Nedra, Leningrad, 400 pp.

- Latal C, Piller W, Harzhauser M (2004) Palaeoenvironmental reconstructions by stable isotopes of Middle Miocene gastropods of the Central Paratethys. Palaeogeography, Palaeoclimatology, Palaeoecology 211(1-2): 157-169. https://doi. org/10.1016/j.palaeo.2004.05.003

- Lukashev VK (1972) Geochemical indicators of hypergenesis and sedimentation. Minsk, Nauka i tekhnika, $320 \mathrm{pp}$.

- Lundquist SP, Worthington TA, Aldridge DC (2019) Freshwater mussels as a tool for reconstructing climate history.
Ecological Indicators 101: 11-21. https://doi.org/10.1016/j. ecolind.2018.12.048

- Matoshko AV, Gozhik PF, Danukalova GA (2004) Key Late Cenozoic fluvial archives of Eastern Europe: the Dniester, Dnieper, Don and Volga. Proceedings of the Geologists' Association 115: 141-173. https://doi.org/10.1016/S00167878(04)80024-5

- Schöne BR, Page NA, Rodland DL, Fiebig J, Baier S, Helama SO, Oschmann W (2007) ENSO-coupled precipitation records (1959-2004) based on shells of freshwater bivalve mollusks (Margaritifera falcata) from British Columbia. International journal of Earth Science 96: 525-540. https://doi.org/10.1007/ s00531-006-0109-3

- Schöne BR, Zhang Z, Jacob D, Gillikin DP, Tütken T, Garbe-Schönberg D, McConnaughey T, Soldati A (2010) Effect of organic matrices on the determination of the trace element chemistry ( $\mathrm{Mg}, \mathrm{Sr}, \mathrm{Mg} / \mathrm{Ca}, \mathrm{Sr} / \mathrm{Ca}$ ) of aragonitic bivalve shells (Arctica islandica) - Comparison of ICP-OES and LAICP-MS data. Geochemical Journal 44(1): 23-37. https://doi. org/10.2343/geochemj.1.0045

- Shevchenko VP, Lyubas AA, Starodymova DP, Bolotov IN, Aksenova OV, Aliev RA, Gofarov MYu, Iglovskij SA, Kokryatskaya NM (2017) Geochemistry of heavy metals in bottom sediments of small lakes in Pymvashor trough (Bolshezemelskaya tundra). Advances in current natural Sciences 1: 105-110. https://www.natural-sciences.ru/ru/article/view?id=36350

- Tesakov AS (2004) Biostratigraphy of the Middle Pliocene Eopleistocene of Eastern Europe (for small mammals). Nauka, Moskva, 247 pp.

- Titov VV (2008) Large mammals of the Late Pliocene of the Northeastern Azov. SSC RAS Publishing, Rostov-on-Don, 264 pp.

- Vangengeym EA, Pevzner MA, Tesakov AS (2005) The age of the borders and the position in the magnetochronological scale of Russia and the Lower Villafranca. Stratigraphy. Geological correlation 5(13): 78-95.

- Wang X, Wei H, Taheri M, Khormali F, Danukalova G, Chen F (2016) Early Pleistocene climate in western arid central Asia inferred from loess-palaeosol sequences. Scientific Reports 6: 1-9. https://doi.org/10.1038/srep20560

- Yan H, Chen J, Xiao J (2014) A review on bivalve shell, a tool for reconstruction of paleo-climate and paleo-environment. Chinese Journal of Geochemistry 33(3): 310-315. https://doi. org/10.1007/s11631-014-0692-0

- Yanshin AL (1989) Quaternary period. Paleontology and archeology. Chisinau, Stiinta, 240 pp. 